\title{
OPTIMALISASI EFEKTIFITAS PEMANFAATAN MACROMEDIA FLASH TERHADAP MINAT BELAJAR SISWA MATA PELAJARAN BIOLOGI
}

\author{
Permata Ika Hidayati \\ Universitas Kanjuruhan Malang \\ permatahidayati@gmail.com
}

\begin{abstract}
Abstrak: Penelitian ini merupakan studi eksperimen di SMAN 9 Malang yang meneliti tentang minat belajar siswa dengan menggunakan media berbasis macromedia flash pada pembelajaran biologi. Penelitian eksperimen yang bertujuan untuk mengetahui perbedaan minat belajar siswa pada kelas yang menggunakan media berbasis macromedia flash dan yang menggunakan media berbasis power point. Populasi penelitian ini adalah seluruh siswa kelas $X$ di SMA Negeri 9. Pengambilan sampel menggunakan teknik Cluster random sampling. Penelitian ini adalah penelitian eksperimen dengan desain Pretest-Posttest Control Group Design. Pengumpulan data yang digunakan adalah dengan menggunakan instrumen angket. Pengujian hipotesis data minat belajar siswa diuji dengan menggunakan statistik Uji-t dan diperoleh hasil macromedia flash memiliki pengaruh yang signifikan. Rata-rata skor kemajuan minat belajar siswa diperoleh pada kelas eksperimen lebih tinggi yaitu sebesar 16,33\% sedangkan rata-rata skor kemajuan minat belajar siswa yang diperoleh pada kelas kontrol hanya sebesar 10,48\%.
\end{abstract}

Kata Kunci: macromedia flash, minat belajar siswa

\begin{abstract}
This research is an experimental study in SMAN 9 Malang that examines student interest by using Macromedia Flash-based media in learning biology. Experimental research that aims to determine differences in the interest of students in the class using Macromedia Flash-based media and the use of media-based power point. The study population was all students in grade X SMAN 9. samples were taken using cluster random sampling technique. This study is an experimental research design with pretest-posttest control group design. Data collection is by using questionnaires. Testing the hypothesis of interest data learning students were tested using a statistical t-test and the results macromedia flash has a significant effect. The average score of the progress of student interest obtained in the experimental class higher at $16.33 \%$ while the average score of the progress of student interest earned on the control class amounted to only $10.48 \%$.
\end{abstract}

Keywords: macromedia flash, student learning interests

\section{PENDAHULUAN}

Perkembangan dunia pendidikan begitu sangat signifikan seiring dengan perkembangan ilmu pengetahuan dan teknologi. Dunia pendidikan selalu diharapkan dapat mengikuti jejak perkembangan teknologi global. Hal ini menjadi sebuah tuntutan, karena pendidikan merupakan modal pokok dalam membangun generasi muda, mencerdaskan kehidupan bangsa, serta mempersiapkan diri menjadi tenaga kerja yang handal dan mampu bersaing. Upaya-upaya yang telah dilakukan oleh pemerintah sangat dibutuhkan guna meningkatkan kualitas sumber daya manusia (SDM) lewat proses pembelajaran yang dilakukan disekolah.

Proses pembelajaran yang dilakukan di sekolah merupakan sorotan utama dalam meningkatkan mutu pendidikan. Tenaga pengajar/guru yang handal diharapkan mampu memberikan peningkatan mutu pendidikan, baik aspek kemampuan berfikir, kepribadian, karakter, dan rasa tanggung jawab. Seorang guru merupakan penutan bagi siswa, baik di lingkungan sekolah maupun di lingkungan sosial/masyarakat. Pada proses pembelajaran, 
guru juga diharapkan dapat memberikan dorongan dan motivasi pada siswa untuk terus belajar dengan memanfaatkan sarana dan prasarana yang dimiliki oleh sekolah.

Sarana dan prasarana yang dimiliki sekolah merupakan salah satu aspek yang sangat mendukung proses pembelajaran, seperti ruang kelas yang luas dan lengkap, media pembelajaran seperti LCD, lapangan olah raga, perpustakaan, dan laboratorium. Kurangnya pemanfaatan sarana dan prasarana khususnya media pembelajaran menyebabkan proses pembelajaran tidak efektif, sulitnya siswa untuk memahami materi yang diajarkan oleh guru dan dapat membosankan bagi siswa. Pada ilmu sains khususnya biologi, pemanfaatan media pembelajaran sangat mendukung seorang guru dalam menjelaskan konsep-konsep fisika sehingga proses pembelajaran lebih baik dan lebih efektif.

Penggunaan media pembelajaran dengan basis teknologi memberikan dampak yang sangat positif bagi kemampuan dan kemauan siswa untuk mengikuti proses pembelajaran. Salah satu media pembelajaran yang dapat diujikan yaitu menggunakan macromedia flash yang merupakan salah satu software komputer yang digunakan untuk mendesain animasi. Dengan proses pembelajaran yang menggunakan macromedia flash siswa tidak hanya menghayal, tetapi siswa dapat melihat langsung konsep yang dijelaskan oleh guru. Hal ini tentunya bisa menarik perhatian siswa dalam kegiatan belajar mengajar di kelas.

Menurut Gerlach \& Ely (Asyhar, 2012:8-9), media pembelajaran memiliki cakupan yang sangat luas, yaitu termasuk manusia, materi, atau kajian yang membangun suatu kondisi yang membuat peserta didik mampu memperoleh pengetahuan, keterampilan atau sikap. Media pembelajaran mencakup semua sumber yang diperlukan untuk melakukan komunikasi dalam pembelajaran, sehingga bentuknya bisa berupa perangkat keras (hadware), seperti komputer, televisi, projektor, dan perangkat lunak (software) yang digunakan pada perangkat keras itu. Briggs (Hamid, 2011:150) menyatakan bahwa media pembelajaran adalah alat-alat fisik untuk menyampaikan materi pelajaran dalam bentuk buku, film, rekaman video, dan media merupakan alat untuk memberikan perangsang bagi peserta didik supaya terjadi proses belajar.

Beberapa langkah/tindakan yang dapat dilaksanakan oleh guru terkait dengan penggunaan media pembelajaran, antara lain: 1) Mengkaji bentuk media pembelajaran yang ada; 2) Mengkaji segenap hal yang terkait dengan penggunaan media pembelajaran, mulai dari bahan ajar/materi pelajaran, tujuan pembelajaran, upaya membangkitkan perhatian dan motivasi peserta didik, melibatkan keaktifan peserta didik, memberikan balikan dan penguatan, sampai dengan perhatian perbedaan karateristik peserta didik; 3) Merancang media pembelajaran sesuai dengan kebutuhan dan tujuan penggunaannya (ceramah, diskusi, eksperimen, simulasi dan lain sebagainya); 4) Membahas rancangan penggunaan bentuk media pembelajaran dengan kepala sekolah dan rekan guru lain untuk mendapatkan tanggapan, bimbingan, bantuan dan arahan; 5) Apabila diperlukan, terhadap penerapan media pembelajaran tertentu yang kurang dikuasai, mencari bantuan ahli yang berasal dari dalam maupun luar sekolah; 6) Menyusun rencana kerja penggunaan media pembelajaran (Agung, 2010:62).

Faktor-faktor yang sangat memengaruhi bahwa suatu media itu cocok dijadikan media pengajaran dan pembelajaran, adalah: a) Tujuan pembelajaran; b) 
Karakteristik siswa; c) Modalitas belajar siswa (audio, visual, dan kinestetis); serta d) Lingkungan ataupun ketersediaan fasilitas pendukung (Hamid, 2011: 152). Sudjana dan Rivai (Arsyad, 2011:24-25) mengemukakan manfaat media pembelajaran dalam proses belajar siswa, adalah: 1) Pembelajaran akan lebih menarik perhatian siswa sehingga dapat menumbuhkan motivasi belajar; 2) Bahan pembelajaran akan lebih jelas maknanya sehingga dapat lebih dipahami oleh siswa dan memungkinkannya menguasai dan mencapai tujuan pembelajaran; 3) Metode mengajar akan lebih bervariasi, tidak semata-mata komunikasi verbal melalui penuturan kata-kata oleh guru, sehingga siswa tidak bosan dan guru tidak kehabisan tenaga, apalagi kalau guru mengajar pada setiap jam pelajaran; 4) Siswa dapat lebih banyak melakukan kegiatan belajar sebab tidak hanya mendengarkan uraian guru, tetapi juga aktivitas lain seperti mengamati, melakukan, mendemonstrasikan, meme-rankan, dan lain-lain.

Model pembelajaran kooperatif adalah rangkaian kegiatan belajar yang dilakukan oleh siswa dalam kelompokkelompok tertentu, untuk mencapai tujuan pembelajaran yang telah dirumuskan. (Ambarjaya, 2012:93). Eggen dan Kauchak (Trianto, 2007:42) menyatakan bahwa, pembelajaran kooperatif merupakan kelompok strategi pengajaran yang melibatkan siswa bekerja secara berkolaborasi untuk mencapai tujuan bersama. Ada empat unsur penting dalam model pembelajaran kooperatif, yaitu: 1) Adanya peserta dalam kelompok; 2) Adanya aturan kelompok; 3) Adanya upaya belajar setiap kelompok; 4) Adanya upaya yang harus dicapai dalam kelompok belajar (Ambarjaya, 2012:94).

$$
\text { Lungren (Trianto, 2007:47) }
$$

menyebutkan bahwa unsur-unsur dasar yang perlu ditanamkan kepada siswa agar pembelajaran kooperatif dapat berjalan efektif adalah: 1) Para siswa harus memiliki persepsi sama bahwa mereka "tenggelam" atau "berenang" bersama; 2) Para siswa memiliki tanggung jawab terhadap tiap siswa lain dalam kelompoknya, di samping tanggung jawab terhadap diri sendiri, dalam mempelajari materi yang dihadapi; 3) Para siswa harus berpandangan bahwa mereka semuanya memiliki tujuan yang sama; 4) Para siswa harus membagi tugas dan berbagi tanggung jawab sama besarnya di antara para anggota kelompok; 5) Para siswa akan diberikan satu evaluasi atau penghargaan yang akan ikut berpengaruh terhadap evaluasi seluruh anggota kelompok; 6) Para siswa berbagi kepemimpinan sementara mereka memperoleh keterampilan bekerjasama selama belajar; dan 7) Para siswa akan diminta mempertanggungjawabkan secara individual materi yang ditangani dalam kelompok kooperatif.

Macromedia flash adalah salah satu program aplikasi yang digunakan untuk mendesain animasi yang banyak digunakan saat ini. Saat membuka situs atau halaman internet tertentu, biasanya terdapat animasi objek grafis yang bergerak dari besar menjadi kecil, dari terang menjadi redup, dari bentuk satu menjadi bentuk lain, dan masih banyak lagi yang lain. Adapun animasianimasi objek grafis tersebut dapat dikerjakan dengan macromedia flash. Macromedia Flash merupakan standar profesional yang digunakan untuk membuat animasi di web. Sejak keberadaannya pertama kali dan digunakan oleh beberapa situs web untuk membuat animasi intro dan permainan, sehingga membuat banyak orang tertarik untuk menggunakannya. Macromedia flash juga mengenalkan bagaimana membuat movie clip, animasi frame, animasi tween motion, serta perintah action script-nya. Beberapa kemampuan macromedia flash lainya adalah 
sebagai berikut: 1) Dapat membuat animasi gerak (motion tween), perubahan bentuk (shape tween), dan perubahan dan transparansi warna (color effect tween); 2) Dapat membuat animasi masking (efek menutupi sebagian objek yang terlihat) dan animasi motion guide (animasi mengikuti jalur); 3) Dapat membuat tombol interaktif dengan sebuah movie atau objek yang lain; 4) Dapat membuat animasi logo, animasi form, presentasi multimedia, game, kuis interaktif, simulasi/visualisasi; 5) Dapat dikonversi dan di-publish ke dalam beberapa tipe seperti *.swf, *.html, *.gif, *.jpg, *.png, *.exe dan *.mov (Asyhar, 2012: 187).

Macromedia flash terdiri dari beberapa bagian, diantaranya sebagai berikut: 1) Menu Bar merupakan barisan menu yang berisi perintah yang digunakan pada Macromedia Flash; 2)Tool panels merupakan barisan menu yang ditandai dengan berbagai ikon dan merupakan jalan pintas untuk menjalankan menu; 3) Stage merupakan bagian dari Macromedia Flash yang digunakan untuk membuat dan meletakkan objek; 4) Timeline merupakan fasilitas yang digunakan untuk membuat, mengatur format animasi yang akan dirancang. Timeline terdiri dari tiga bagian yaitu Scene, Layer, dan Frame; 5) Panel

berfungsi untuk mengontrol atau memodifikasi berbagai atribut pada objek atau animasi secara tepat; 6) Properties berfungsi untuk mengatur properti objek yang aktif.

Salah satu faktor utama untuk mencapai kesuksesan dalam segala bidang, baik berupa studi, hobi, kerja dan aktivitas apapun adalah minat. Tumbuhnya minat dalam diri seseorang akan melahirkan perhatian untuk melakukan sesuatu dengan tekun dalam jangka waktu yang lama, lebih fokus, mudah untuk mengingat, memahami dan tidak mudah bosan dengan apa yang dipelajarinya. Hilgard (Slameto, 2010:57) memberi rumusan tentang minat adalah sebagai berikut: "Interest is persisting tendency to pay attention to and enjoy some activity or content". Minat adalah kecenderungan yang tepat untuk memperhatikan dan mengenang beberapa kegiatan. Kegiatan yang diminati seseorang, diperhatikan terus menerus yang disertai dengan rasa senang. Jadi berbeda dengan perhatian, karena perhatian sifatnya sementara (tidak dalam waktu yang lama) dan belum tentu diikuti dengan perasaan senang, sedangkan minat selalu diikuti dengan perasaan senang dan dari situ diperoleh kepuasan. (Slameto, 2010:57). Minat merupakan kesadaran seseorang, bahwa suatu subjek, seseorang, suatu soal atau suatu situasi yang mengandung sangkutpaut dengan dirinya. (Arikunto, 2010:217).

Minat besar pengaruhnya terhadap belajar, karena bila bahan pelajaran yang dipelajari tidak sesuai dengan minat siswa, siswa tidak akan belajar dengan sebaikbaiknya karena tidak ada daya tarik baginya. Bahan pelajaran yang menarik minat siswa, lebih mudah dipelajari dan disimpan, karena minat menambah kegiatan belajar.

Berdasarkan tinjauan di atas, minat belajar adalah proses penyesuaian diri atau tingkah laku siswa yang dilandasi rasa senang, ketertarikan terhadap suatu pelajaran untuk memperhatikan dan ikut terlibat dalam aktivitas belajar karena menyadari pentingnya atau bernilainya hal yang dipelajari tersebut.

\section{METODOLOGI PENELITIAN}

Penelitian ini telah dilaksanakan di SMA Negeri 9 Malang yang terletak di Jalan Puncak Borobudur 1, Mojolangu, Kecamatan Lowokwaru, Kota Malang, Propinsi Jawa Timur. Waktu penelitian dilaksanakan pada semester genap tahun ajaran 2012/2013 yakni pada tanggal 15 April 2013 sampai 10 Mei 
2013. Waktu penelitian disesuaikan dengan jadwal pelajaran di sekolah. Pelaksanaannya pada hari selasa untuk kelas kontrol dan hari rabu untuk kelas eksperimen.

Populasi pada penelitian ini adalah seluruh siswa kelas X di SMA Negeri 9 Malang yang menerima mata pelajaran biologi pada tahun ajaran 2012/2013. Jumlah populasi dalam penelitian ini terdiri dari tujuh kelas yaitu $\mathrm{X}^{1}$, $x^{2}, x^{3}, x^{4}, x^{5}, x^{6}$ dan $x^{7}$. Pengambilan sampel dalam penelitian ini menggunakan teknik Cluster random sampling atau penarikan sampel secara berkelompok, yang dirandom adalah kelasnya. (Ary dkk, 2011:201).

Pengambilan sampel dilakukan dengan cabut lot untuk mendapatkan dua kelas dari seluruh kelas yang ada, yang dianggap mewakili seluruh populasi pada kelas $X$ yang berjumlah 7 kelas. Kelas $X^{1}$ dan $X^{3}$ merupakan sampel yang terpilih, selanjutnya untuk menentukan kelas eksperimen dan kelas kontrol dilakukan dengan melemparkan uang koin. Hal ini dilakukan untuk menghindari adanya faktor memihak diantara salah satu kelas. Setelah melemparkan uang koin diperoleh kelas $\mathrm{X}^{1}$ sebagai kelas eksperimen dan kelas $\mathrm{X}^{3}$ sebagai kelas kontrol. Desain penelitian yang digunakan yaitu desain Pretest-Posttest Control Group Design yang digambarkan seperti berikut.

\begin{tabular}{|ll|l|l|l|}
\hline $\mathrm{KE}$ & $:$ & $0_{1}$ & $\mathrm{X}_{1}$ & $0_{2}$ \\
\hline $\mathrm{KK}$ & $:$ & $0_{2}$ & $\mathrm{X}_{2}$ & $0_{2}$ \\
& & & & \\
\hline
\end{tabular}

Gambar 1. Desain Penelitian

Keteterangan:

$\mathrm{KE}=$ Kelompok kelas eksperimen

$\mathrm{KK}=$ Kelompok kelas kontrol

$\mathrm{X}_{1}=$ Kelas yang diberi perlakuan media

berbasis macromedia flash
$\mathrm{X}_{2}=$ Kelas yang diberi perlakuan media

berbasis power point

$0_{1}=$ Minat belajar siswa pada kelas eksperimen dan kontrol sebelum diberi perlakuan.

$\mathrm{O}_{2}=$ Minat belajar siswa pada kelas eksperimen dan kontrol setelah diberi perlakuan. (Arikunto, 2010:210)

Teknik pengumpulan data yang digunakan dalam penelitian ini yaitu angket dan observasi. Jenis skala yang digunakan yaitu Skala Likert. Instrumen yang berupa angket digunakan untuk mengukur minat belajar siswa pada mata pelajaran biologi, sedangkan observasi digunakan untuk melihat aktivitas guru dalam pembelajaran dan sebagai pendukung pembahasan.

\section{HASIL DAN PEMBAHASAN}

Penelitian dengan penerapan media berbasis macromedia flash merupakan sebuah penelitian eksperimen yang dilakukan di kelas X SMA Negeri 9 Malang Tahun Ajaran 2012/2013. Data hasil penelitian berupa skor minat belajar siswa yang diperoleh melalui angket yang diberikan pada responden. Selanjutnya data tersebut diolah untuk mengetahui normalitas, homogenitas dan uji hipotesisnya dengan menggunakan statistik ujit. Selain data minat belajar siswa, peneliti juga mengumpulkan data hasil belajar siswa sebagai data pendukung yang diperoleh melalui instrumen berupa tes uraian. Data hasil penelitian skor minat belajar siswa yang diperoleh pada pre-test dan post-test dapat dilihat pada tabel 1 berikut. 
Tabel 1. Skor minat belajar siswa

\begin{tabular}{|c|c|c|c|c|c|c|c|c|}
\hline \multirow{3}{*}{ No } & \multirow{3}{*}{$\begin{array}{l}\text { Jenis } \\
\text { Angket }\end{array}$} & \multirow{3}{*}{ Kelas } & \multicolumn{6}{|c|}{ Skor Masing-Masing Indikator } \\
\hline & & & \multicolumn{2}{|c|}{ Partisipasi } & \multicolumn{2}{|c|}{ Perhatian } & \multicolumn{2}{|c|}{$\begin{array}{c}\text { Perasaan } \\
\text { Senang }\end{array}$} \\
\hline & & & Min & Maks & Min & Maks & Min & Maks \\
\hline \multirow{2}{*}{1.} & \multirow{2}{*}{ Pre-test } & Eksperimen & 16 & 36 & 18 & 34 & 23 & 38 \\
\hline & & Kontrol & 22 & 39 & 17 & 32 & 22 & 36 \\
\hline \multirow{2}{*}{2.} & \multirow{2}{*}{ Post-test } & Eksperimen & 28 & 48 & 26 & 38 & 29 & 47 \\
\hline & & Kontrol & 24 & 42 & 25 & 38 & 29 & 46 \\
\hline
\end{tabular}

Berdasarkan tujuan penelitian yang dikemukakan adalah untuk mengetahui apakah terdapat perbedaan antara kelas yang menggunakan media pembelajaran berbasis macromedia flash dan kelas yang menggunakan media berbasis power point.

Tahap awal yang dilakukan peneliti adalah menyiapkan instrumen penelitian untuk mengumpulkan data berupa angket. Jenis angket yang digunakan yaitu angket dengan item tertutup. Sebelum digunakan pada penelitian, terlebih dahulu angket divalidasi untuk mengetahui apakah angket layak digunakan untuk mengukur minat belajar siswa. Proses validasi dilakukan melalui beberapa tahap, yaitu melalui bimbingan dosen, guru ahli dan uji coba. Validasi yang dilakukan melalui bimbingan dosen dan guru ahli mencakup redaksi kalimat dan bahasa yang diterapkan pada pernyataan. Sedangkan validasi melalui uji coba angket dilakukan di kelas selain sampel penelitian. Peneliti melakukan uji coba angket di kelas $\mathrm{X}$ dengan jumlah responden sebanyak 27 siswa. Hasil Uji coba angket kemudian diolah dengan melakukan pengujian validitas dan reliabilitas menggunakan rumus product moment dengan koefisien reliabel sebesar $\mathrm{r} 11=0,878$.

Sebelum kedua kelas mendapatkan perlakuan, terlebih dahulu diberikan pre-test berupa angket awal yang bertujuan untuk mengetahui minat belajar awal siswa. Setelah itu, kedua kelas diberi perlakuan yang berbeda. Pada kelas eksperimen dibelajarkan dengan menggunakan macromedia flash dan kelas kontrol dibelajarkan dengan menggunakan power point. Dalam pembelajaran dengan menggunakan media berbasis macromedia flash berisi animasi-animasi yang berhubungan dengan konsep-konsep biologi modern sehingga siswa lebih tertarik untuk belajar dibandingkan dalam pembelajaran yang menggunakan media berbasis power point. Salah satu materi biologi yang diajarkan dengan menggunakan macromedia flash yaitu materi tentang biogas. Pada materi biogas sangat cocok dibuat animasi yang memberikan pemahaman pada siswa serta dari animasi yang ditampilkan siswa dapat menganalisis dan menjelaskan konsep biogas itu sendiri. Pada materi biogas membahas tentang proses pembuatan biogas dan biogas sebagai teknologi alternatif pengganti gas LPG. Animasi yang ditampilkan bertujuan untuk mengajak siswa berpikir ke arah yang lebih abstrak, sehingga siswa dengan mudah memahami dan mengetahui penerapan konsep biogas dan proses pembuatan biogas dalam kehidupan sehari-hari.

Model pembelajaran yang digunakan dalam proses pembelajaran adalah model pembelajaran kooperatif yang terdiri dari enam fase. Dari keenam fase tersebut penggunaan media pembelajaran memiliki peran pokok pada fase pertama dan kedua. 
Pada fase pertama memberikan apersepsi dan memotivasi siswa dengan menampilkan animasi tentang konsep biogas yang dialami dalam kehidupan sehari-hari, yang bertujuan mengajak siswa untuk berfikir dan memudahkan untuk masuk ke materi yang akan diajarkan. Fase kedua yaitu menyampaikan informasi, memberikan penjelasan tentang materi dengan menampilkan animasianimasi tentang konsep biogas.

Setelah diberi perlakuan, kedua kelas diberikan post-test yang bertujuan untuk mengetahui minat belajar siswa setelah diberikan perlakuan media macromedia flash dan media power point. Dari hasil skor pre-test dan post-test minat belajar siswa dapat diketahui skor kemajuan minat belajar siswa untuk masing-masing indikator. penggunaan media pembelajaran pada kelas eksperimen lebih baik dibandingkan pada kelas kontrol.
Dari 27 siswa pada kelas eksperimen 1 siswa kriteria minat baik, 17 siswa kriteria minat cukup dan 9 siswa kriteria minat kurang untuk partisipasi. Untuk perhatian 2 siswa kriteria minat baik, 9 siswa kriteria minat cukup dan 16 siswa kriteria minat kurang. Sedangkan untuk perasaan senang 8 siswa kriteria minat baik, 15 responden kriteria minat cukup dan 4 siswa kriteria minat kurang. Pada kelas kontrol dari 26 siswa, 12 siswa kriteria minat cukup dan 14 siswa kriteria minat kurang untuk partisipasi. Untuk perhatian 11 siswa kriteria minat cukup dan 15 siswa kriteria minat kurang. Sedangkan untuk perasaan senang 11 siswa kriteria minat cukup dan 15 siswa kriteria minat kurang. Persentase siswa yang termasuk kategori minat kurang, cukup, baik dan sangat baik pada kelas eksperimen dan kelas kontrol dapat dilihat pada gambar 2 berikut.

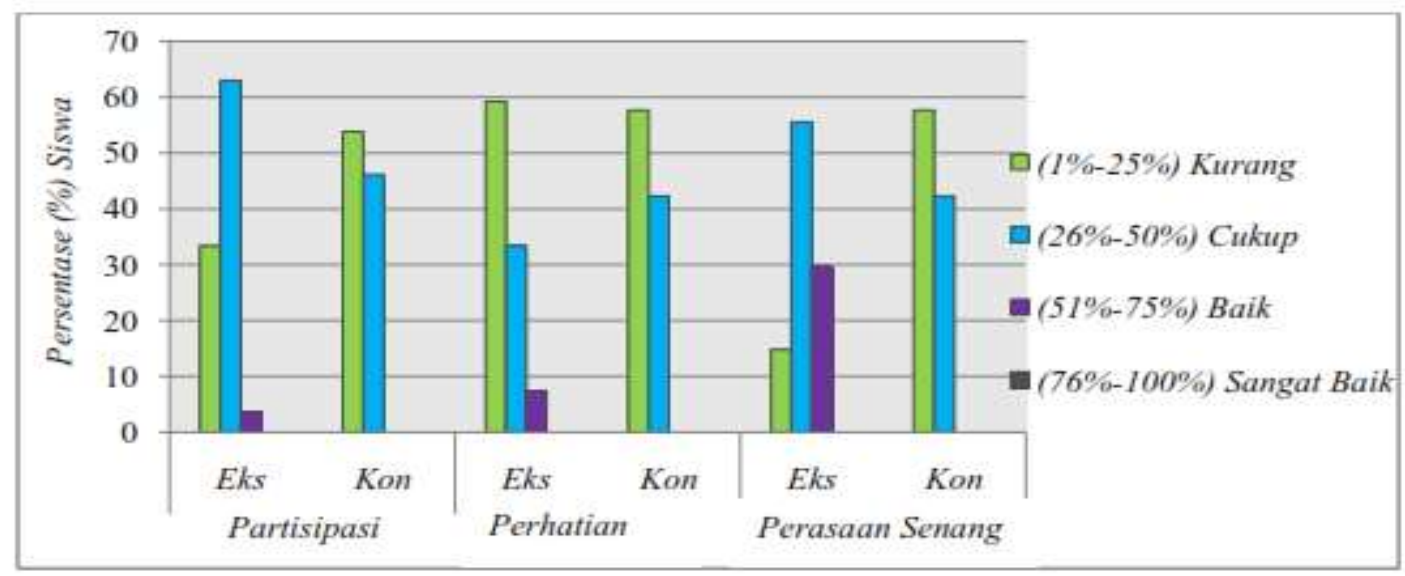

Gambar 2. Distribusi Jumlah Responden Terhadap Indikator Minat Belajar Pada Kelas Eksperimen dan Kelas Kontrol.

Persentase kemajuan minat belajar siswa pada masing-masing indikator pada kelas eksperimen lebih tinggi dibandingkan pada kelas kontrol. Perbandingan kemajuan minat belajar siswa pada kelas eksperimen dan kelas kontrol yang tertinggi yaitu pada indikator partisipasi sebesar 7,47\%. Hal ini menunjukkan bahwa, perlakuan yang diberikan pada kedua kelas khususnya media pembelajaran yang digunakan pada masing- masing kelas sangat mempengaruhi minat belajar siswa. Proses pembelajaran menggunakan macromedia flash dapat melatih siswa dalam mengajukan pendapat dan memberikan komentar tentang animasi yang ditampilkan, mendorong siswa untuk lebih giat belajar terutama dalam mengerjakan tugas-tugas yang diberikan oleh guru. Persentase kemajuan minat belajar siswa dapat dilihat pada gambar 3 berikut. 


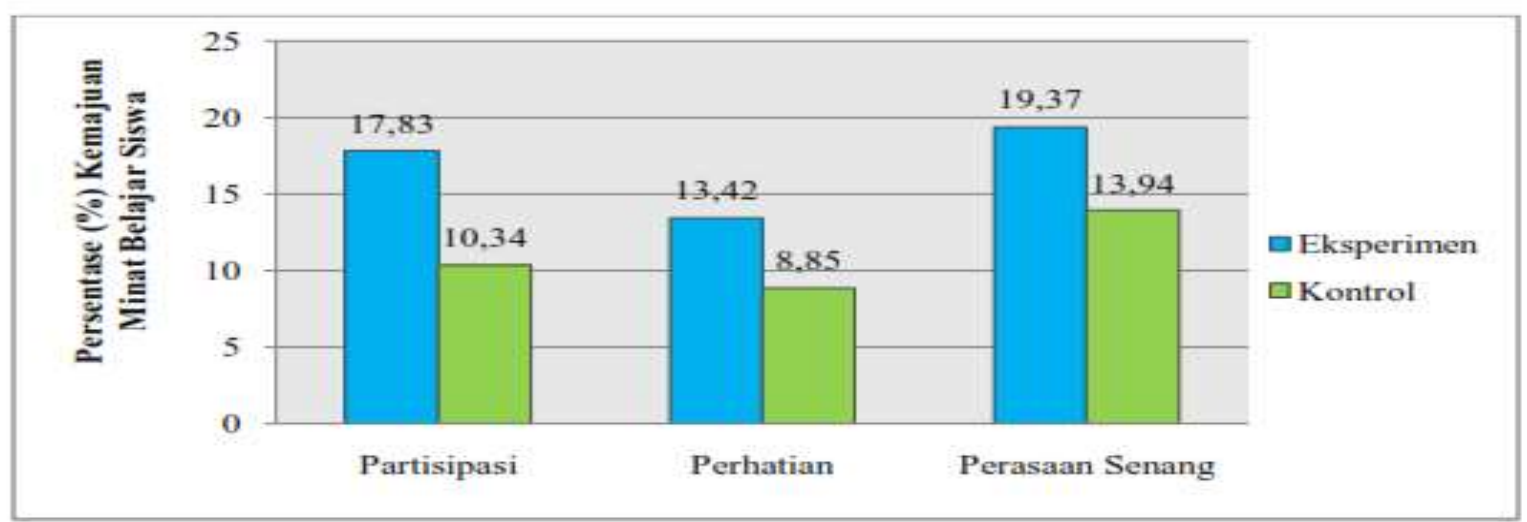

Gambar 3. Persentase (\%) Kemajuan Minat Belajar Siswa Pada Kelas Eksperimen dan Kelas Kontrol Untuk Setiap Indikator.

Selanjutnya dari hasil penelitian diperoleh perbandingan minat belajar siswa antara siswa laki-laki dan perempuan. Minat belajar siswa laki-laki pada kelas eksperimen dan kelas kontrol lebih tinggi dibandingkan siswa perempuan. Perbandingan skor minat belajar siswa laki-laki dan perempuan pada kelas eksperimen sebesar 2,27 sedangkan pada kelas kontrol perbandingan skor minat belajar siswa laki-laki dan perempuan sebesar 3,23. Salah satu faktor yang mempengaruhi minat belajar siswa laki-laki lebih tinggi dibandingkan siswa perempuan yaitu teknologi informasi dan komunikasi (TIK) yang diterapkan dalam proses pembelajaran. Siswa laki-laki lebih tertarik dengan hal-hal yang baru, terutama yang berhubungan dengan teknologi masa kini. Oleh karena itu, tidak mengherankan jika dalam proses pembelajaran dengan menerapkan media berbasis macromedia flash dan power point minat belajar mereka lebih tinggi. Perbandingan skor minat belajar siswa laki-laki dan perempuan pada kelas eksperimen dan kelas kontrol dapat dillihat pada gambar 4.

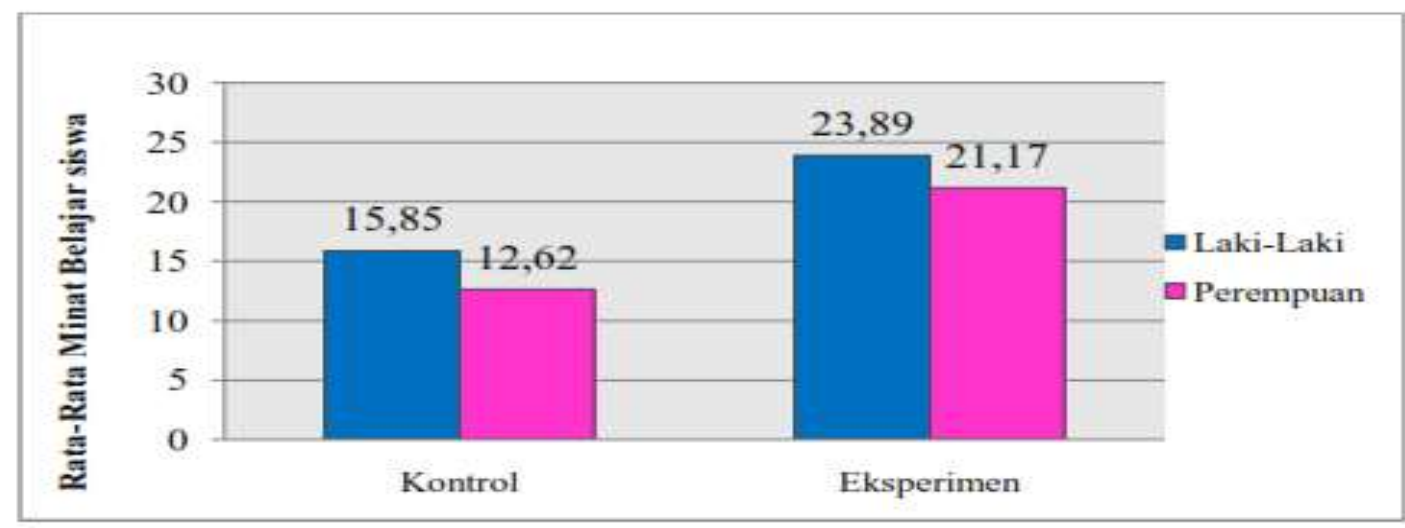

Gambar 4. Perbandingan Rata-Rata Minat Belajar Siswa Laki-Laki dan Perempuan.

Minat memiliki pengaruh yang sangat besar terhadap hasil belajar siswa. Semakin tinggi minat seorang siswa terhadap mata pelajaran, maka semakin tinggi pula hasil belajar yang diperoleh. Sebaliknya, semakin rendah minat belajar siswa terhadap mata pelajaran, maka semakin rendah hasil belajar yang diperoleh. Skor rata-rata hasil belajar 
siswa pada kelas eksperimen lebih tinggi dibandingkan skor rata-rata hasil belajar siswa pada kelas kontrol. Selisih skor ratarata hasil belajar siswa untuk kedua kelas sebesar 12,74. Hal ini membuktikan bahwa minat sangat berpengaruh terhadap hasil belajar siswa. Semakin tinggi skor minat belajar siswa, semakin tinggi pula hasil belajar yang diperoleh atau sebaliknya. Perbandingan skor rata- rata hasil belajar siswa pada kelas eksperimen dan kelas kontrol dapat dilihat pada gambar 5 berikut.

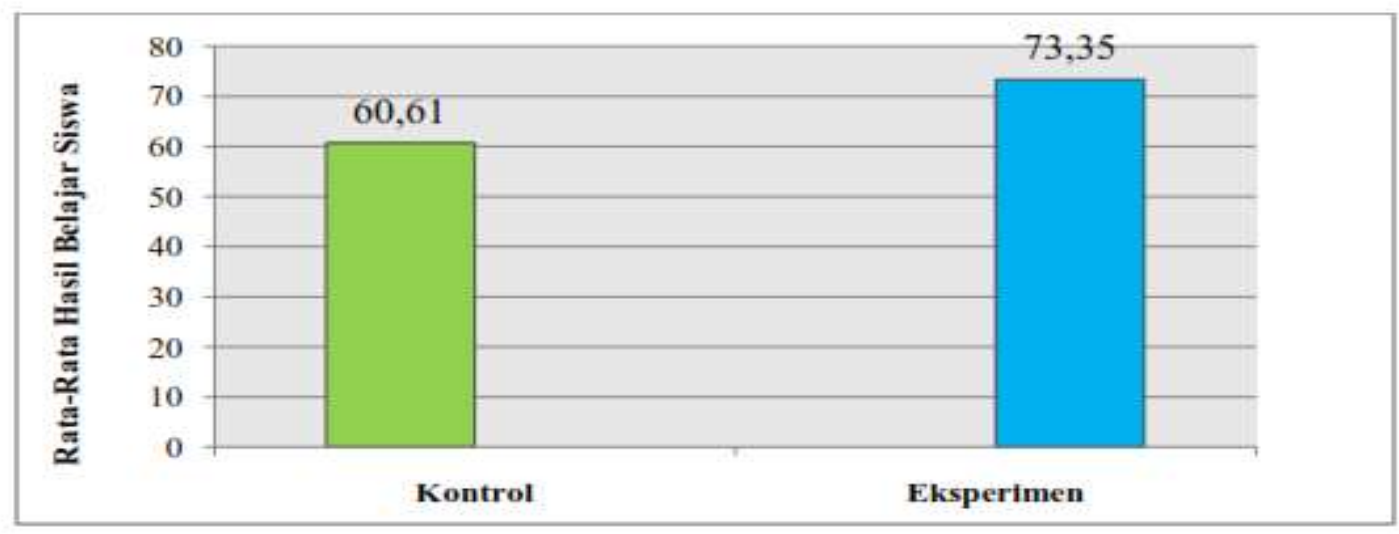

Gambar 5. Perbandingan Skor Rata-Rata Hasil Belajar Siswa

Berdasarkan hasil penelitian di atas, sangat jelas bahwa terdapat perbedaan yang signifikan antara minat belajar siswa yang diajarkan menggunakan media berbasis macromedia flash dan yang diajarkan menggunakan media berbasis power point. Dalam hal ini minat belajar siswa yang diajarkan menggunakan media berbasis macromedia flash lebih tinggi dibandingkan minat belajar siswa yang diajarkan power point dengan hasil pengujian hipotesis $t_{\text {hitung }} \square t_{\text {tabel }} \square 4,47 \square 2,00$, yang menunjukkan bahwa kriteria pengujian hipotesis Ho ditolak dan H1 diterima.

\section{SIMPULAN DAN SARAN}

\section{Saran}

Berdasarkan hasil penelitian dan pembahasan yang diperoleh dapat disimpulkan bahwa, media pembelajaran sangat berpengaruh terhadap minat dan hasil belajar siswa. Pengaruh tersebut dapat dilihat dari perbedaan yang signifikan antara minat belajar siswa pada kelas eksperimen dan kelas kontrol. Dari hasil pengujian hipotesis diperoleh bahwa terdapat pengaruh yang signifikan penggunaan media pembelajaran macromedia flash untuk meningkatkan minat belajar siswa pada mata pelajaran biologi.

Hal ini menunjukkan bahwa, hipotesis $\mathrm{H}_{0}$ ditolak dan $\mathrm{H}_{1}$ diterima yang berarti terdapat perbedaan yang signifikan dalam hal minat belajar siswa pada kelas yang menggunakan macromedia flash dengan kelas yang menggunakan power point. Berdasarkan hal tersebut, penggunaan macromedia flash sangat berpengaruh terhadap minat belajar siswa.

\section{Saran}

1. Kesuksesan hasil belajar dipengaruhi oleh media pembelajaran yang digunakan. Dari hasil penelitian diharapkan guru dapat menggunakan media pembelajaran berbasis macromedia flash dalam pembelajaran biologi, untuk meningkatkan minat dan memudahkan siswa dalam memahami materi yang diajarkan. 
2. Untuk para peneliti, hasil penelitian ini dapat dijadikan dasar untuk melakukan penelitian lebih lanjut tentang masalah yang sama, baik ditingkat SMP maupun SMA atau yang sederajat.

\section{DAFTAR PUSTAKA}

Agung, Iskandar. 2010. Meningkatkan Kreativitas Pembelajaran Bagi Guru. Jakarta: Bestari Buana Murni.

Ambarjaya S.Beni.2012. Psikologi Pendi-dikan \& Pengajaran. Yogyakarta: CAPS. Arikunto, Suharsimi. 2010. Manajemen Penelitian. Jakarta: Rineka Cipta

.Arsyad, Ashar. 2011. Media Pembelajaran. Jakarta: PT Raja Grafindo Persada.

Ary, Donald, dkk. 2011. Pengantar Penelitian Dalam Pendidikan. (Terjemahan Arief Furchan) Yogyakarta: Pustaka Pelajar.

Asyhar, Rayandra. 2012. Kreatif Mengembangkan Media Pembelajaran. Jakarta: Ciputat. Djamarah B. Syaiful. 2008. Psikologi Belajar. Jakarta: Rineka Cipta.

Hamid, Sholeh. 2011. Metode Edutainment. Jogjakarta: DIVA Press. Muataqim \& Wahib. 2010. Psikologi Pendidikan. Jakarta: Rineka Cipta.

Slameto. 2010. Belajar \& Faktor-Faktor Yang Mempengaruhinya. Jakarta: Rineka Cipta. Sugiyono. 2012. Metode Penelitian Kuantitatif, Kualitatif dan $R \quad \& \quad D$. Bandung: Alfabeta.

Trianto.2007. Model-Model Pembelajaran Inovatif Berorientasi Konstruktivistik. Jakarta: Prestasi Pustaka 